\title{
Az MTA Társadalomtudományi Kutatóköz- pont Szociológiai Intézet konferenciája az Ózon világnapja alkalmából
}

\author{
Király Gábor \\ https://doi.org/10.51624/SzocSzemle.2018.3.6
}

Kettős apropója volt az Éghajlatváltozás és Egészség című konferenciának, melyet a MTA TK Szociológiai Intézet szervezett 2018. szeptember 16-án. Egyrészről szeptember tizenhatodika az évfordulója az 1987-ben megszületett montreali jegyzőkönyvnek, mely szigorúan korlátozta a légköri ózont pusztító anyagok használatát. A nevezetes napra azóta az Ózon világnapjaként emlékeznek a környezetvédők. Másrészről Antal Z. László, a MTA TK Szociológiai Intézet munkatársa a konferencián mutatta be új könyvét.

A montreali egyezmény a nemzetközi környezetpolitika egyik legsikeresebb megállapodásaként vált ismertté. Az egyezmény célja az volt, hogy drasztikusan korlátozza a légköri ózonra veszélyes klór-, fluor- és brómalapú hütő- és hajtógázok használatát. Erre azért volt szükség, mert a nyolcvanas évekre minden kétséget kizáróan sikerült bizonyítani, hogy ezek a vegyi anyagok felelősek az ózonkoncentráció csökkenéséért. Az 1987-es jegyzőkönyvben foglalt kivonási határidőket az ózonréteg regenerációjának felgyorsítása érdekében többször is szigorították, mígnem 1997-ben teljesen betiltották ezeknek az anyagoknak a használatát.

Az egyezmény jelentősége kettős. Egyrészt sikerült elérni a kitüzött célt, hiszen a kétezres évek elején már mérhető volt az ózonkoncentráció emelkedése. Másrészről mintaként és példaként szolgál arra, hogy lehetséges globális környezeti problémára nemzetközi együttmüködésen alapuló megoldást találni és azt a gyakorlatban alkalmazni. A globális környezeti problémák egyik sajátossága, hogy hatásukat valamilyen formában a társadalom minden tagja érzékeli. Az ózonréteg elvékonyodásával erősödő ultraibolya sugárzásnak elsősorban az élettani hatása (növeli a bör öregedésének, a szürke hályog és a bőrrák kialakulásának kockázatát) az, ami kiemelten fontos társadalmi problémává tette a jelenséget. Ezzel szemben az éghajlatváltozás társadalmi hatásai ennél szerteágazóbbak, hiszen egyaránt érintik az egészségügy, a migráció, az élelmezés, a lakhatás területét és még egy sor egyéb területet. Ezt a sokszínüséget képviselte a konferencia programja is.

A konferenciát Botos Barbara, az Innovációs és Technológiai Minisztérium Klímapolitikáért felelős helyettes államtitkára köszöntötte. Előadásában kiemelte, hogy az éghajlatváltozás ténye ma már nem kérdés és nem vita tárgya. A helyettes államtitkár 
asszony szerint a klímabarát zöld innovációk és beruházások mutatják az utat, amerre Magyarországnak is mennie kell, ha nem akar lemaradó ország lenni. Ezen az úton az egyik első lépés biztosan a Minisztérium irányításával megvalósuló ún. „hazai IPCC jelentés" elkészítése lesz. A Minisztérium célja, hogy a nemzetközi szervezethez hasonlóan feltárja és szintetizálja az éghajlatváltozással kapcsolatos hazai tudományos eredményeket, majd azokat közérthető formában a döntéshozók rendelkezésére bocsássa.

Antal. Z. László két előadással is szerepelt a programban. Az első előadása végigkövette, milyen előzmények vezettek a montreali jegyzőkönyv megszületéséhez. Ezek az előzmények tulajdonképen a hütés technológiai fejlődésének fordulópontjai. Az 1920-as években életszínvonal-emelő vívmányként érkeztek meg a háztartásokba az első elektromos hütőszekrények, melyek lassan felváltották az addig használt jégszekrényeket. Ezek a korai berendezések azonban olyan hütőfolyadékokkal müködtek, melyek gyúlékonyak és súlyosan mérgezők voltak. Számtalan balesetet és halálesetet követően érkezett az újabb technológiai áttörés: a harmincas években megjelentek a halogénezett szénhidrogének, amelyek biztonságos és hatékony megoldást kínáltak háztartási és ipari hütésre. Néhány évtized alatt a hütőszekrények luxuscikkből általános háztartási felszereléssé váltak, ezzel párhuzamosan pedig emelkedni kezdett a halogénezett szénhidrogének légköri koncentrációja. A történet folytatását a bevezetöben már elmeséltük. Antal Z. László felhívta rá a figyelmet, hogy fontos látni a történetben rejlő dinamikát: egy modernizációs igényre egymást váltva érkeznek technológiai innovációk, anélkül, hogy az új technológiák használatának környezeti és egészségügyi hatásait ismernénk. Kérdés, hogy elkerülhetők-e az ilyen jellegü kockázatok.

Az éghajlatváltozásról diskurzust folytatni nem lehet a meteorológia nézőpontja megismerése nélkül. A konferencián Bartholy Judit előadása foglalta össze az éghajlatváltozással kapcsolatos legfontosabb és legfrissebb tudnivalókat. Az ELTE Meteorológiai Tanszék vezetőjének előadásában a legnyugtalanítóbb megállapítások a közelmúltban tapasztalt hőmérsékleti anomáliákhoz voltak köthetők. Ilyen hőmérsékleti anomáliák például az elmúlt években mért rekordmelegek az északi sarkköri vidékeken. Tekintetbe véve, hogy a globális éghajlatrendszerben minden mindennel összefügg, ilyen esetekben nem csak azt kell megvizsgálni, hogy mit okoz az ilyen szélsőségesen magas hőmérséklet az északi sarkkörön, hanem azt is, hogy mit okoz ez a Föld más pontjain. A kulcskérdés a meteorológusok számára pedig annak megállapítása, hogy vajon elszigetelt egyedi esetekről van-e szó, vagy valóban megtörtént már a globális éghajlatrendszer egyensúlyi állapotból történő kibillenése, ami visszafordíthatatlan változásokat eredményezne a regionális éghajlati viszonyokban.

Antal Z. László második előadásában $A$ gyógyítás társadalmi beágyazottsága címü könyvét mutatta be a közönségnek. A könyv valójában a szerző kandidátusi értekezése, melynek kiadására eddig még nem került sor, ugyanakkor témáját tekintve semmit nem vesztett aktualitásából. Különösképpen igaz ez, ha az éghajlatváltozás által előidézett egészségügyi kihívásokra gondolunk, melyek nagy részét ma még nem is ismerjük. Antal könyvében azt állítja, hogy minden társadalom rendelkezik gyógyító tudással, 
azonban ezek különböző integrációs formák kombinációiban vannak jelen. Ilyen integrációs forma például az önszabályozó öngyógyítás, önsegítés és jótékonykodás, a redisztributív állami vagy önkormányzati ellátás és a piaci szervezésű magánellátás.

A különböző formák közötti arányváltozások feltárásával közelebb kerülhetünk rendszerszintü változások hatásainak megértéséhez. A könyv alapjául szolgáló értekezés elkészítésekor az egészségügyi ellátórendszer rendszerváltás utáni átalakulása adott okot az integrációs formák vizsgálatára. Antal Z. László megállapítása szerint a posztszocialista társadalom egészségügyi rendszere csak azért nem omlott össze, mert müködni kezdtek az önszabályozáson alapuló integrációs formák, melyek tulajdonképpen a társadalom immunrendszerének is tekinthetők. A következő évtizedek kérdése, hogy az éghajlatváltozás által előidézett egészségügyi kockázatok társadalmi szintű kezelésében a különböző integrációs formáknak milyen szerep jut majd.

Páldy Anna, az Országos Közegészségügyi Intézet Klímaváltozás-egészséghatás Előrejelzése Csoport vezetőjének előadása tulajdonképpen ott folytatta, ahol Antal Z. Lászlóé befejezte. Az éghajlatváltozás egészségkárosító hatása kapcsán a legtöbben a legszennyezettségre, valamint a nyári rekkenő hőségre és az azzal kapcsolatos egészségügyi kockázatokra gondolnak. Páldy Anna előadásából ugyanakkor kiderült még, hogy számos egyéb kihívással is szembe kell majd néznünk, akár már rövid távon is. Várhatóan emelkedni fog a víz és az élelmiszerek által közvetített betegségek előfordulásának gyakorisága, elég ha csak az árvizek utáni fertőzésekre gondolunk. Ennél is nagyobb kockázatot hordoznak majd azok az új faktorok, amelyek az élőhelyeik egyre északabbra tolódásával jelennek meg nálunk, és olyan betegségeket hordozhatnak és terjeszthetnek, melyek kezelésére még nem vagyunk felkészülve. A szélsőséges időjárási események rövid távon, a megváltozó éghajlati viszonyok pedig hosszú távon okozhatnak súlyos víz- és élelmiszerhiányt, de foglalkoznunk kell a természeti katasztrófák miatt kitelepítettek mentális egészségével is. Az egészségügy esetében különösen igaz, hogy a megelőzést és az alkalmazkodást egyaránt szem előtt tartó, nem csak egészségügyi, hanem komplex szakpolitikára lesz szükség.

Huszár András az Innovációs és Technológiai Minisztérium Klímapolitikai föosztályát képviselte a konferencián. A montreali jegyzőkönyv kapcsán a közönség betekintést nyert abba, hogy milyen kötelezettségeket jelent az ország számára egy nemzetközi környezetvédelmi egyezmény részesének lenni. Magyarország esetében a Minisztérium egyik főosztályaként müködő Nemzeti Klímavédelmi Hatóság a felelős a fluortartalmú üvegházhatású gázokkal, valamint az ózonréteget lebontó anyagokkal kapcsolatos adatgyűjtésért és adatszolgáltatásért. Ez ma huszonhétezer felhasználót és nyolcvanezer regisztrált berendezést jelent. A Nemzeti Éghajlatváltozás Stratégia dekarbonizációs víziója szerint az alkalmazkodás mellett a kibocsátáscsökkentésnek is nagy hangsúlyt kell kapnia a jövőben. Minden nemzetközi kötelezettségvállalást figyelembe véve a cél, hogy 2050-ig nyolcvanöt százalékkal csökkenjen az üvegházhatású gázok hazai kibocsátása. 
A nemzetközi színtéren már kiterjedt kutatások foglalkoznak az éghajlatváltozás biztosítási ipart érintő hatásaival. Ezek a kutatások egy nagyon egyszerü összefüggésből indulnak ki: az egyre gyakoribb és intenzívebb szélsőséges időjárási események egyre súlyosabb természeti katasztrófákat fognak előidézni, amelyek egyre nagyobb vagyoni kárral fognak együtt járni, erre pedig fel kell készülniük a biztosítóknak is. Hazánkban ugyanakkor ez a megközelítés még nem kapott kiemelt figyelmet. Oláh Attila a Groupama Biztosító képviseletében elmondta, hogy a biztosítók már ma is nagyon nehezen tudnak megbízható becsléseket készíteni, az egyre szélsőségesebbé váló időjárás pedig ezt nyilvánvalóan csak még nehezebbé fogja tenni a jövőben. Az éghajlatváltozáshoz való alkalmazkodásra azonban már most is lehet hatása a biztosítóknak, ha olyan termékeket értékesítenek, amelyek például zöld technológiák alkalmazására vagy az egészséges életmód fenntartására ösztönöznek.

A konferencia programjában helyet kapott két kifejezetten orvostudományi témájú előadás. Takács István a D-vitamin szerepéről, Wikonkál Róbert pedig az UV sugárzás ártalmairól és a megelőzés lehetőségeiről tartott előadást. A két téma szorosan összefügg az éghajlatváltozással és az ózonréteg állapotával, népegészségügyi vonatkozásuk miatt pedig egyértelmüen helyük van egy társadalomtudományi konferencia programjában. A D-vitamin kapcsán érdekes volt megismerni azt a folyamatot, melynek a végén sikerült konszenzusra jutniuk a hazai szakmai szereplőknek a D-vitamin korcsoportra bontott szükséges napi dózisairól. Talán a közönség soraiban ülők között is volt olyan, akinek újdonságot jelentett, hogy a mindenki által vitaminnak ismert D-vitamin valójában nem az, hanem a szervezet által elöállított hormon. Tekintetbe véve, hogy előállítása 80-90 százalékban napsugárzásfüggő, kiemelten fontos, hogy októbertől márciusig is biztosítsuk a feltételeket a szinten tartáshoz. Ez lehet rendszeres napfürdőzés vagy D-vitamin-készítmény fogyasztása.

A nap Wikonkál Róbert előadásában is kiemelt szerepet kapott, a hangsúly itt azonban már az ártalmas hatásokon volt. Az ma már nem tudományos vita tárgya, hogy a túlzott UV sugárzás élettani hatása rendkívül kártékony, hiszen ez ma az egyik első számú daganatkeltő ágens. A gond az, hogy az UV sugárzást nem tudjuk kikerülni, megelőző és alkalmazkodó lépéseket azonban tudunk tenni egészségünk megóvása érdekében. Ezen a ponton válik fontossá a szakmai alapokon nyugvó tudatformálás szerepe, ami hitelesen tájékoztat a biztonságos napozásról, a naptejhasználat előnyeiről vagy a szolárium veszélyeiről. Sajnos tennivaló még bőven van, hiszen a bőrrákkal diagnosztizált esetek száma évről évre még mindig növekszik, pedig tudatos védekezéssel és rendszeres orvosi ellenőrzéssel jelentős javulást lehetne elérni.

Tóth Zoltán, az Országos Meteorológiai Szolgálat légkörfizikusa az ózonpajzs és az éghajlatváltozás kapcsolatáról tartott előadást. Az előadás két szempontból is jól egészítette ki a korábban elhangzottakat. Egyrészről árnyalta az ózonréteg regenerációjáról szóló bizonyítékokat azzal, hogy felvázolta a mérési módszertan nehézségeit, valamint megtudhattuk, hogy a több mint két évtizede rendszeresen észlelt nyári ózonhiány keletkezésének okára még mindig nincs tudományos magyarázat. Feltehetően szerepe 
van ebben az éghajlatváltozás következményeként nyáron emelkedő hőmérsékletnek, habár a probléma rendkívül komplex természetéből adódóan nagyon nehéz szignifikáns kapcsolatokat kimutatni.

A konferencia programjában helyet kapott egy már megvalósult jó gyakorlat bemutatása is. Nagyvárosi környezetben az épített felületek felmelegedése és hővisszasugárzása miatt a nyári hőség különösképpen próbára teszi az emberi szervezetet. Egy pécsi kísérlet bebizonyította, hogy az egyik lehetséges megoldás ennek a hatásnak a mérséklésére, ha az utcák fölé árnyékoló napvitorlákat feszítenek ki. Girán János elöadásában a városüzemeltetés, a népegészségügyi intézet és a környezetmérnökök együttműködésének sikeres történetét ismerhette meg a hallgatóság. Az árnyékolt felületek alatt elért minimális hőmérséklet-csökkenés is jelentős komfortérzet-növekedést okoz az alattuk sétálóknak. Ott, ahol nem lehet erős lombozatú fákat telepíteni, ezek a napvitorlák jó megoldást jelenthetnek elviselhetőbbé tenni a nyári hőséget városi környezetben.

Ferencz Zoltán záró előadása tulajdonképpen keretbe foglalta a konferenciát. A Társadalomtudományi Központ munkatársa előadásában a szociológiai nézőpont fontosságára hívta fel újra a figyelmet, amikor kihangsúlyozta, hogy az ember által előidézett éghajlatváltozás mindenképpen hatással lesz az emberek életére. Ferencz Zoltán szerint a European Survey legfrissebb éghajlatváltozással foglalkozó adatfelvételének eredményeiből az látszik, hogy az emberek tisztában vannak a következményekkel, de még nem aggódnak miattuk. Pedig a kockázat érzékelése lenne az első lépés a cselekvéshez vezető úton, legyen szó akár az üvegházhatású gázok kibocsátásának csökkentéséről vagy az éghajlatváltozás hatásaihoz való alkalmazkodásról.

A konferencia ehhez kínált remek alapot, hiszen számos olyan témát érintett, ahol szükség lenne jól kidolgozott tudatformálásra és a közvélemény tájékoztatására. Az éghajlatváltozás egészségügyi és tágabb értelemben vett társadalmi hatásainak vizsgálata egyértelműen indokolta és a jövőben indokolni fogja a konferencia tudományterületeken átívelő programját. Nagyon szép példát mutatott arra, hogy lehetséges izgalmas párbeszéd akár nagyon eltérő tudományágak között is. 